\title{
The Slowness
}

\section{From Latent Aspects to Relevant Agency}

ZORANA PROTIĆ

Faculty of Architecture, University of Zagreb 
Most of the artificial assembly that surrounds us is made through a series of processes, and the finalised objects emerge from an operation of multitude of devices. Since each space carries with it something of the being that designed it, every artefact hides some technical invention. The general trend of market uniformity, technological mass, and a constant flow of materials that stimulate our senses, reduces our ability to consider alternatives and possible deviations from the omnipresent. One of the potentials of education is to slow down the process and draw our attention to a material world. Material world itself can be considered from two sides: as a structural matter or as a conceptual strategy. In such a way, the material character of architecture and concentration on the matter becomes a substantive medium of design. The research course operates outside of contemporary tasks, slowing the pace and providing time for perception. A collection of short assignments under a common name The [sub]Stance uses a slow process of recognizing the material as a potential starting point for contemplation. Considering the relationship between forms, materials, space, and processes, students develop a specific sensibility for physical substance around them, while simultaneously expanding their area of knowledge. By exploring alternative approaches that develop a new look at the standard construction and its unquestionable role in architectural practice, they broaden conceptual reflections in the field of materiality, skill, and technique. Such alternative strategies do not tend to develop or establish new constructional approaches, but to research already existing possibilities and use the usual techniques for achieving innovative solutions. The main assignment was focused on exploring construction strategies such as ready-made, bricolage, boundary vs. condition, living systems, and time. Thus, they become a didactic model for the interpretation of materials of everyday culture that enable students to create their design tools. In the end of the course there are two short assignments, speculative and experimental, which are - using a set of strategies - emphasizing the process rather than the product.

\section{THE PREFACE: MODEL — NORM — SYSTEM}

Does building make an architectural gene? Do we know how to use the technique? In what way do we use the technique? What is material knowledge? How to transmit an abstract idea with that knowledge into the material world? Can the technique be a design tool? Does the architect need to be an expert to use it? How important is the bond between pragmatism and technique? What is the importance of knowing the origin of 
the material or of the technology? Can the material have its meaning or narrative, and that way can it play a key role in the project? Which Question is important; what material is it or what does it provide? Should the built-in material be more than what it is - a finished product or raw material? Is the material more than its appearance or its physical specificity?

\section{THE INITIAL ASSIGNMENT: FROM PHENOMENON THROUGH MATTER TO PROCESS}

Last year's exhibition of The Thirteenth Triennial of Croatian Sculpture brings together the works of around one hundred authors that make up a cross-section of the three-year work. By visiting the exhibition, it is necessary to change the focus of observation from aesthetic appearances to material reality. Now the sculptures no longer represent the reflexive of the author, but they are just artificial objects. Artistic pretension is transmitted into an act of production. Each artefact is preceded by technique, a certain skill or a technological process that differs in the complexity of the design. By contemplating at the exhibits, it is essential to separate three examples of a study with some common relation such as a form or material or technique or something else. Through the analysis of selected sculptures, it is necessary to distinguish and relate its initial concept and production technique with the emphasis on re-discovering the direct relationship between craft and design product. 
' ON THE LEVEL OF CONTENT, MY CONCEPTION WAS BASED ON THE OBSERVATION THAT WE HAVE FIXED IMAGES IN MIND THAT DON'T MATCH THE REALITIES THEY STAND FOR. SAME THING WITH BREAD: THERE'S AN IMAGE OF WHAT BREAD USUALLY LOOKS LIKE. SO WE PUT UP A DISPLAY EVERY MORNING OF "DAILY BREAD" FROM ALI OVER THE WORLD THAT DEMONSTRATED HOW THERE ARR ASPECTS FAR BEYOND THE ROUND LOAF OF BAKED DOUGH THAT GO INTO WHAT BREAD LOOKS LIKE: FROM STORAGE PRACTICES-WE HAD CRISP
BREADS THAT WERE CIRCULAR DISCS WITH A HOLE IN THE MIDDLE-TO THE USE OF BREAD DOUGH TO EXPRESS SEXUAL SYMBOLISM. WE WANTED TO DISPROVE THE NOTION THAT "FORM FOLLOWS FUNCTTON." WE ALSO BXHIBTTED A WIDE VARIETY OF HAMMIRS, FROM SURGEON'S MALLETS TO AN AUTO BODY WORKER'S HAMMER, WHICH WERE ALI BASED ON THE SAME STANDARD FORM BUT THEN DEVIATED FROM THAT STANDARD DEPENDING ON THEIR SPECIFIC FUNCTION. Hans Hollein

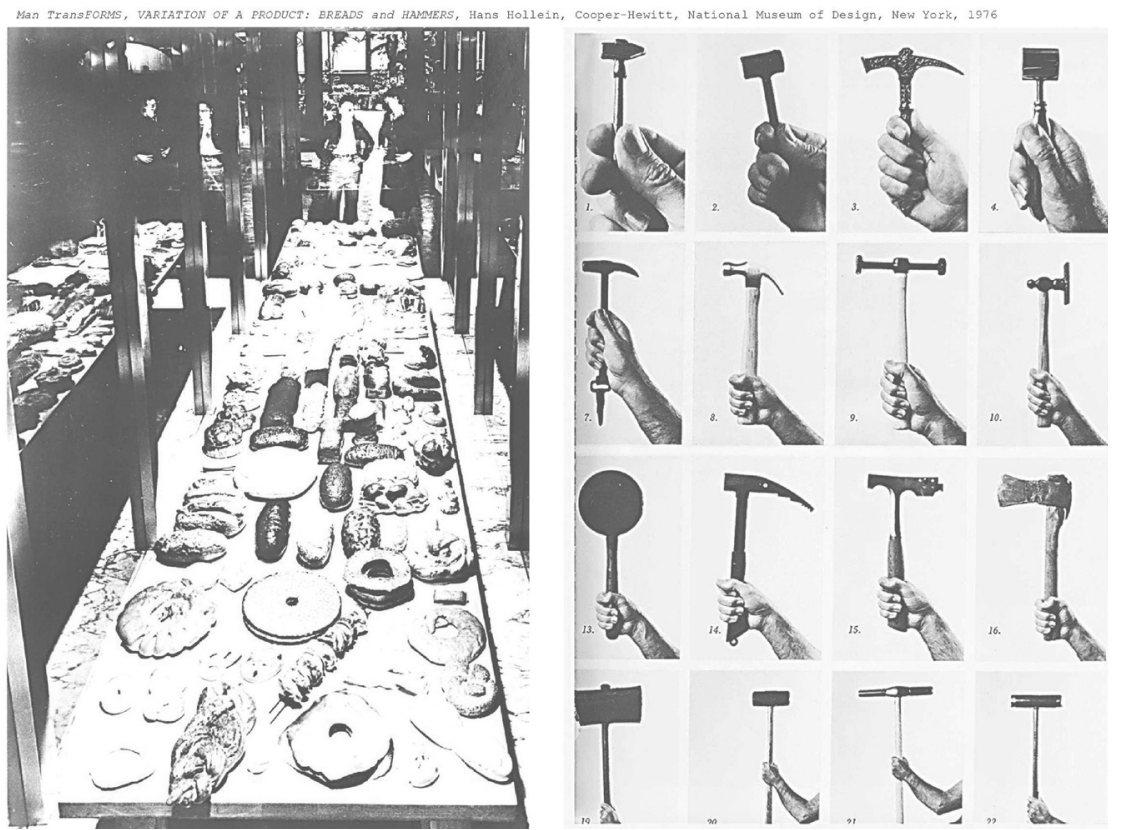


THERE ARE MRNY SUCH THINGS ALI AROOND THAT WE DON'T QURSTION. CREATING SOMETHING THAT WOULD MRRGE TNTO THIS

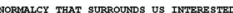
Te. (a) no 10n TO ACCEPT THIS THING BEFORE THII EYES, EVEN IF THEY FOCND IT STRRNGE. WHEN SOMETHING IS UNDEFTMED IN TERMS OF MECHANISM OR CONCEPT, IT CAN EXIST Prex or propue's Dectsion 

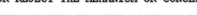

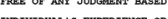
INDIVIDUAL'S EXPERIEYCE OI SUBJECTIVUTY. FHIS TRBLE IS ONE ATEEAPN AN THAT. Junya Ishigami
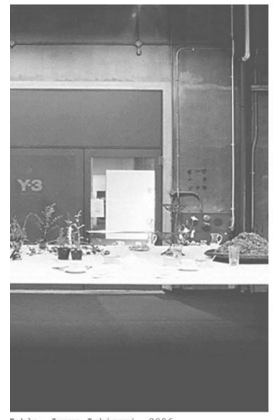

Cable, Junya Ishigami, 2006
I NAS ALNOST SURE THAT THIS WOULD $\mathbf{B Z}$ FOREVER, THAT I WOULD NEVER BE ABIE TO BUILD. I has ALMOST ABSOLUTE QUIET ABOUT IT BVT OE COUPSE SOMEWHERE DEEP TM MY MAND I WAS य.

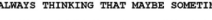
THERE WOULD BE A POSOIBILTTY TO MRKX SOMETHING, EVEN A SMALI THING, JUS TO CHECK THE FERLING OF GETTING INSIDE A BUILDING THAT YOU'VE DESIGNED. THIS IS A VERY IMPORTANT THING THAT YOU CAN STSP INSTDE THE जPCE SPACE TAR YOU CAE WHAT THE DRAWTO WAS AND HOW IT LOOK IN RERI LIFE. IT'S A VERY STRONG AI STRANGE FEELING. OF COURSE, I WA THINKING ABOUT THIS, AND AT SOMI MOMENT I UNDERSTOOD THAT THIS IS THE DAY WHEN I CAN TRY, REGARDLESS IF I'U

THES WAS SORPOSED TO STAY FOR A FEW THYS WAS SUTPOSED TO STAY FOR A FEW
TEXRS. THE DAR WAS MADE FOR A COUPLE YEXRS. THE EAR WAS MADE FOR A COUR
OF MONYHS ONIX, BUI IT IS ETPRAGE OF MOMTHS ONIX, BUI IT IS ETPRN

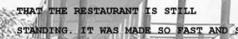
CGEAPL T. HK CLIENT THOUGHT THAT IT IS PROBABLY TOR TNO OR THREE YEARS :

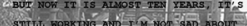

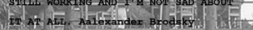

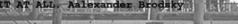

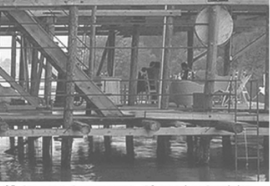
95 Degrees Restaurant, Alexander grodsky
with oleg ovsy, Fifogoro Fesort, Moscow
xegion, Fussia, 2000
ECHOING THEIR USE OF STARDARD ELEMENT BUIDDIMG PRODUCTS, THE EXHIBITION IS ORGANTSED TY A SEOUTICE OF DOONS

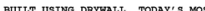

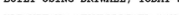
UAIQUUTOUS STANDARDISED CONSTRUCTIOH SYSTEM. NORMALLYY RIDDEN BEHTMD LAYE OF PLASTRRBOARD IN OFTICES, SCHOOLS AND HOSPITALS, THE EXHIBITTON USES SLENDER STEEL STUDS LEFT EXPOSED FRAMTNO ARTNORKS, VIEHS ACROSS GALLERIRS AND THE FURMTTUSE MTTUTI

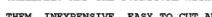
17m. TO QUTCK TO ASSERBLE, THE DRTWAIL STUD IS THR MATUPAL DRSCENDENT OF AMRRICA BUILDING PRODUCTS. FOLLOWING THE EAMESINA TRADTTYON, THESE EVERYDAY COMMERCIAL MATERTALS ARE TURAED TO CREATE A PLAYFUL AND OPEN SPATIAL NARRATIVE THROUGH OST OE TUY YOSE

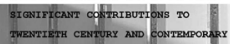
TWENIIIETH CENTUSY A DESIGN. Tom kmerson

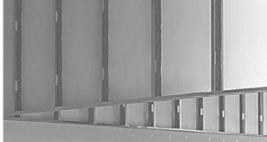

SKOGHALI Is A gMaIL COMNOSITY II SEARCH OF AN IDENTITY. UP URTII NOW, ITS IDENITTY HAS BERA STRONGLY TDENTIFIRD AS A PAPER MILL TOWN. IIT FACT, MOST OF SKOGHALI HAS BEEN BUILT BY THE PAPER MILL, TICLUDING MOST OF THE HOUSHMG AAD THE CHURCH. I PROROSE TO DESTGN AND BUILD A NEW,

CONTEMPORARY STRUCTURE TO HOUSE THE NEW gxOGHALL KONSTHALI. THIS STRUCTURE WIIL RE BUILT COMPIETELY IN PAPRR PRODUCRD BY THR PAPRR ИILL, IN CLOSE COLLABORATION MITH LOCA ARCHITECTS AND BUILDERS. THE DESTGK NILI REFLECT THE BEST OF CONTEMPORARY SWEDISH ARCHITBCTURE IN

ITS MTMTMAI EIEEAMCE AND RESPECT FOR THE ENVTROMMENT. IT HILL ALSO REFLECT THI GRMEROUS COMAT TMENT OF THE MATI LOCAL INDUSTRY IN THE CREATION OF A FORNARD LOOKTIG STRUCTURE ARD IssTrтUTION THAT WTH ЕROJECT gKOOHALL INTO TFE FUTURE. AY ITS D

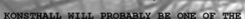
MOST ADURICED CONTEMPOBRRY PAPER STRUCTURR EIVRR CREATRD WOR STRUCTURR RVRR CREATRD DOR 1) The Skoghall Konsthal1, Alf fredo Jaax,
Skoghall, Sweden, 2000
THE SINGLE - WALL HOUSE, CRRISTIAN KEREZ， ZURICH， SWI TEERLNSD, $2004-2007$ 'REDUCTTOM MAKES ARCHITECTURAI BLEMRATS MOFE RADICAL NND VI BIBIE THE TOPIC OF RRDUCTION DOES NOT MRAN STMPLIFICATION BUT QUITE THE COMTrA BBCAUSE That waLl has to DO EVERYTHING: IT IEADS THE STAIRCASE FROM ONE TO THE OTHER SIDE OF THE HOUBE, IT IS A LOADEEARTMO STRUCTUR,

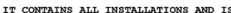
THE ORLY ELARN OFERING THIS GLAS Daverow AND QUALITY, AS WELL DIRRCTING THR SPACE TOWARDS THE CUTSIDE. THIS ONE WALL IS IMTERESTING ONLY QRCAUSE OF ITS MULTIPLE SIGNIFICANCE.

Christian Kerez

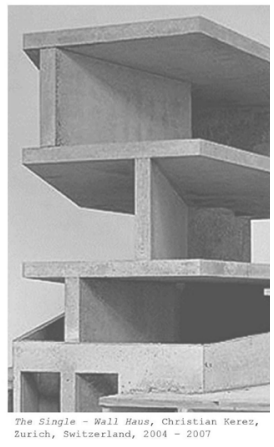




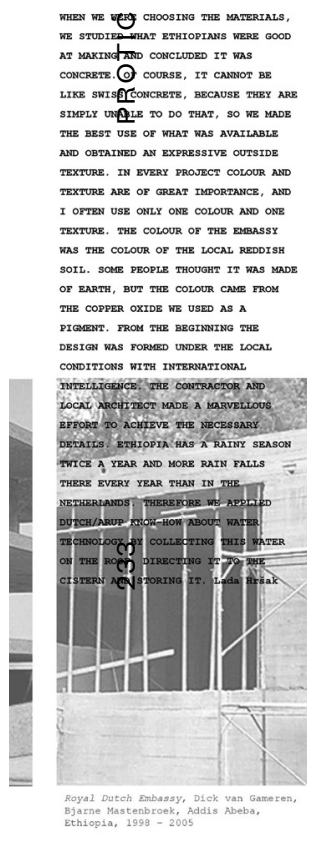

THE PRODUCTION PROCESS FOR INSTANT INVENTORY, ALTHOUGH STILI IN THE SPHERE OF 'DO IT YOURSELF' PRINCIPLE CAME CLOSER TO THE INDUSTRIAL METHOD OF MARKING THE SHAPES. IN THIS CASE, THE NEGATIVE FORM OF THE MOLD IS REPLACED BY A POSITIVE, OR THROUGH THE MULTIPLICATION TOOL. USING A HOT FORMING DEVICE, A THIN LAYER OF PLASTIC MATERIAL (HIGH IMPACT POLYSTYRENE SHEET) IS FORMED BY A POSITIVE MOLD OR BY THE TOOL MENTIONED ABOVE. INSTEAD OF CASTING ANY LIQUID MATERIAL THAT WILL SUBSEQUENTLY HARDEN IM THE NEGATIVE BY THE CHEMICAL REACTION, THE RIGID
MATERIAI IS NOW SOFTENED BY HEATING AND THE HARD, FADED PLASTIC MASS BECOMES A POLISHED "SHEET" THAT IS FOLDED OVER THE TOOL AND THEN VACUUMED IN A DISTINCTIVE SHAPE. THE INITIAL CONSTRUCTION ELEMENT IN INSTANT INVENTORY, THROUGH THE MULTIPLE LOGIC, OR MASS PRODUCTION OF EQUIVALENT PIECES, CONVERT TO THE FINAL PRESENTATION MODE. INSTANT INVENTORY REPRESENTS A NEW POINT IN COMTNG CLOSER TO THE INDUSTRIAI MODE OF PRODUCING ARTWORK. Predrag Pavić

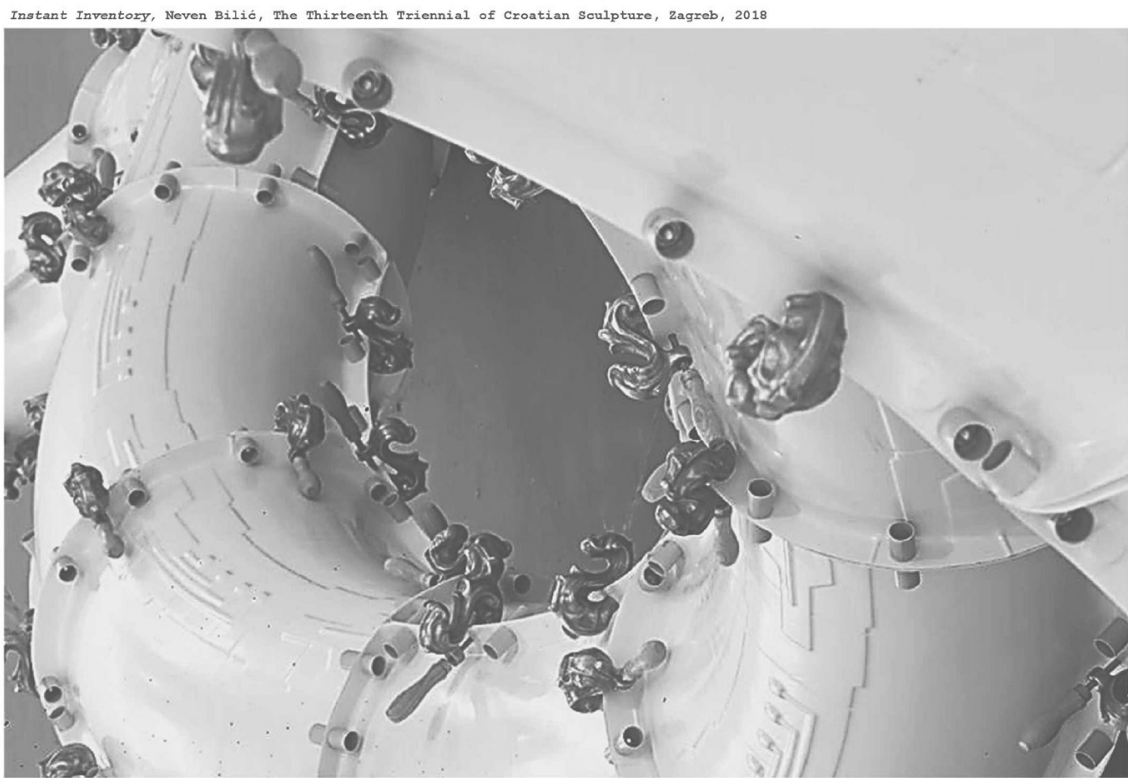

